\title{
RESPON MASYARAKAT SAGERAT TERHADAP KEBERADAAN PASAR PINASUNGKULAN KOTA BITUNG
}

\author{
Ronald H. Mamongan \\ Ventje V. Rantung \\ Ribka M. Kumaat \\ Jean J. F. Timban
}

\begin{abstract}
ABSRACT
This study aims to determine the response of Sagerat commnuity towartd the existence of Pinasungkulan Market at Bitung City. The determination of the sample is determined by accidental sampling technique. The data used are primary data and secondary data. Primary data was obtained by questionnaires filled by community members as respondents of this study who are live around the market. The research used Likert Scale method. Secondary data obtained from Market Office and Market Management Agency Pinasungkulan at Bitung City. Data analysis in this study used descriptive analysis based on the answers that given in the questionnaire respondents. The result of the research shows that from 4 variables which is measured Pinasungkulan market is pleased by the sorrounding community; it can be seen from the total number of scores obtained in 3,815, where in the scale of measuring the variable number of score 2801-4200, means the market is pleased by its the surrounding community.
\end{abstract}

Keywords: response, Sagerat society, Pinasungkulan Market, Bitung City

\begin{abstract}
ABSTRAK
Penelitian ini bertujuan untuk mengetahui respons anggota masyarakat Sagerat terhadap keberadaan Pasar Pinasungkulan Kota Bitung. Penentuan sampel ditentukan berdasarkan kebetulan yang di pandang cocok sebagai sumber data atau teknik accidental sampling. Data yang digunakan adalah data primer dan data sekunder. Data primer diperoleh langsung dari masyarakat di sekitar pasar yang menjadi responden dengan bantuan daftar pertanyaan (kuesioner) yang telah disiapkan terlebih dahulu. Data sekunder diperoleh dari Dinas Pasar dan Dinas Pengelola Pasar Pinasungkulan Kota Bitung. Analisis data dalam penelitian ini menggunakan analisis deskriptif berdasarkan jawaban yang di berikan responden pada kuesioner yang menggunakan metode skala Likert. Hasil penelitian menunjukkan bahwa dari 4 variabel yang di ukur, Pasar Pinasungkulan disenangi oleh anggota masyarakat Sagerat, di lihat dari keseluruhan jumlah skor yang didapatkan sebesar 3.815, di mana di dalam skala pengukuran variabel jumlah skor 2801-4200, artinya pasar tersebut disenangi oleh masyarakat sekitar.
\end{abstract}

Kata kunci: respon, masyarakat Sagerat, Pasar Pinasungkulan, Kota Bitung 


\section{PENDAHULUAN}

\section{Latar Belakang}

Pasar tradisional merupakan pasar yang berperan penting dalam memajukan pertumbuhan ekonomi ragional dan memiliki keunggulan bersaing secara alamiah. Keberadaan pasar tradisional ini sangat membantu, tidak hanya bagi pemerintah daerah tetapi juga para masyarakat yang menggantungkan hidupnya dalam kegiatan berdagang, karena didalam pasar tradisional terdapat banyak aktor yang memiliki arti penting dan berusaha untuk mensejahterakan kehidupannya baik itu pedagang, pembeli, pekerja panggul dan sebagainya. Pasar tradisional terdapat banyak interaksi yang ditemukan, dimana para pedagang pasar tradisional tidak membeli suatu barang dagangan yang akan mereka jajakan di tokonya dalam jumlah yang besar dari agen, hal ini disebabkan karena keterbatasan modal yang mereka miliki tidak mencukupi untuk membeli barang-barang dalam jumlah yang besar kemudian juga mereka tidak memiliki fasilitas yang lengkap untuk menyimpan barang dagangan terlalu banyak. Keunggulan dari pasar tradisional adalah para pembeli dan penjual bertemu langsung untuk melakukan suatu transaksi jual beli, didorong pula dengan defenisi dari pasar itu sendiri dimana pasar adalah suatu tempat bertemunya penjual dan pembeli dalam satu lokasi dan melakukan transaksi jual beli baik itu barang ataupun jasa, tindakan ini merupakan suatu nilai lebih untuk pasar tradisional dimana pembeli dan penjual dapat melakukan proses tawar menawar barang yang akan dibeli oleh pembeli, mutu dari barang yang akan dibeli dan yang terpenting menumbuhkan kesan akrab antara pembeli dan penjual. Salah satu pasar tradisional di Kota Bitung adalah pasar Pinasungkulan Sagerat, walaupun pasar ini masih tergolong baru dan mengalami masalah dalam pembangunan pasar tradisioanal tidak membuat pasar tradisional ini berhenti beroperasi. Kebijakan relokasi yang tidak berjalan sesuai yang diharapkan dimana banyak pedagang yang kembali lagi kepasar sebelumnya, dan konsumen yang tetap berbelanja di pasar sebelumnya, namun hal ini tidak menyebabkan pasar tradisional Pinasungkulan Sagerat ditutup, masih banyak pedagang dan konsumen yang berbelanja di pasar tersebut, terutama masyarakat yang tingal di sekitar pasar tersebut. Oleh karena itu dalam penelitian ini Penulis bermaksud membahas respon masyarakat sagerat terhadap keberadaan pasar pinasungkulan Kota Bitung.

\section{Perumusan Masalah}

Berdasarkan latar belakang di atas, maka pokok perumusan masalah dalam penelitian ini adalah bagaimana Respon Mayarakat Sagerat Terhadap Keberadaan Pasar Pinasungkulan Kota Bitung.

\section{Tujuan Penelitian}

Tujuan dari Penelitian ini adalah agar supaya bisa mengetahui bagaimana Respon Mayarakat Sagerat terhadap Keberadaan Pasar Pinasungkulan Kota Bitung.

\section{Manfaat Penelitian}

Memberikan informasi pada penulis tentang Respon Masyarakat Sagerat terhadap Keberadaan Pasar Pinasungkulan Bitung dan juga Sebagai bahan referensi untuk penelitian selanjutnya.

\section{METODOLOGI PENELITIAN}

\section{Waktu dan Tempat Penelitian}

Lokasi penelitian ditentukan secara sengaja artinya daerah penelitan dipilih berdasarkan tujuan tertentu yang dipandang sesuai dengan tujuan penelitian. Daerah penelitian ditetapkan di kota Bitung yang bertempat di Kelurahan Sagerat Weru Satu dan Sagerat Weru 2, yaitu Kelurahan yang terdekat dengan pasar Pinasungkulan. Penelitian ini dilaksanakan selama tiga bulan dari bulan Januari 2015 - April 2015.

\section{Metode Pengambilan Data}

Metode pengumpulan data dilakukan dengan menggunakan Metode survey. Jenis data yang diperoleh data primer dan data sekunder. Data primer diperoleh langsung dari masyarakat Kelurahan Sagerat Weru 1 dan Sagerat Weru 2 dan data sekunder diperoleh dari pengelola pasar 


\section{Metode Pengambilan Sampel}

Dalam penelitian ini populasi yang akan diteliti jumlahnya tak terhingga, sehingga sampel yang akan diambil harus tepat jumlahnya, untuk menentukan jumlah sampel yang diperlukan dapat dicari dengan rumus (Djarwanto dan Subagyo, 2000)

$$
n=1 / 4\left[\frac{Z_{\alpha / 2}}{E}\right]^{2}
$$

Keterangan :

$\mathrm{n}=$ Sampel

$\mathrm{Z}=$ Angka yang menunjukkan penyimpangan nilai variable dari mean

$\mathrm{E}=$ Error

Nilai $\alpha: 0,05$ ditetapkan besarnya kesalahan tidak sampai 0,1. Disini akan didapat perhitungan sebagai berikut :

$n=1 / 4\left[\frac{Z_{0,05 / 2}}{0,1}\right]^{2}=1 / 4\left[\frac{1,96}{0,1}\right]^{2}$

$\mathrm{n}=96,04$

Maka banyaknya sampel yang akan diambil 96,04 orang maka dibulatkan menjadi 100 konsumen. Teknik pengambilan sampel yang digunakan dalam penelitian ini adalah accidental sampling yaitu teknik pengambilan sampel berdasarkan kebetulan, yaitu siapa saja yang secara kebetulan yang bertemu dengan peneliti dijadikan sampel bila dipandang orang yang kebetulan ditemui itu cocok sebagai sumber data, dalam hal ini peneliti mendatangi rumah-rumah masyarakat atau lingkungan Kelurahan Sagerat hingga mencapai 100 responden (Sugiyono, 2005).

\section{Konsep Pengukuran Variabel}

Karakteristik responden, mencakup:

1. Jenis Kelamin (laki-laki/perempuan)

2. Umur, usia responden terakhir deinyatakan dalam tahun. Pekerjaan, jenis pekerjaan apa yang ada pada responden

3. Tingkat Pendidikan, di lihat dari pendidikan terakhir yang ditempuh responden

4. Pendapatan, jumlah penghasilan perbulan yang di dapat responden

5. Alamat, tempat tinggal responden berada

Variabel-variabel yang akan diukur dalam penelitian ini adalah:
1. Harga adalah jumlah uang yang telah disepakati oleh calon pembeli dan penjual untuk ditukar dengan barang atau jasa dalam transaksi bisnis normal (Tandjung, 2004).

Dalam penelitian ini harga indikatornya :

a) Harga yang terjangkau

b) Harga sesuai dengan kualita

c) Harga bevariasi

2. Pelayanan adalah setiap tindakan atau perbuatan yang dapat ditawarkan oleh suatu pihak kepada pihak lain, yang pada dasarnya bersifat intangible (tidak berwujud fisik) dan tidak menghasilkan kepemilikan sesuatu (Tjiptono, 2002:6). Selanjutnya pelayanan, indikatorya :

a) Pelayanan penjual yang cepat

b) Sikap penjual yang ramah

c) Menitik beratkan pada kepuasan konsumen

3. Lokasi. Lokasi berhubungan dengan tempat di mana pasar itu berada apakah pasar tersebut strategis atau tidak startegis (Lupioadi,2001). Lokasi, indikatornya:

a) Mudah transportasinya

b) Waktu tempuh yang dibutuhkan singkat

c) Lokasi strategis

d) Lokasi dekat dengan pusat keramaian

4. Keragaman barang merupakan kelengkapan barang yang dijual dan ketersediaan barangbarang tersebut dalam hal ini sangat beragam, beragam dan tidak beragam.

Keragaman, indikatornya:

a) Kelengkapan produk yang dijual

b) Produk yang bervariasi

c) Ketersediaan produk yang dijual

d) Macam merek yang tersedia

\section{Skala Pengukuran Variabel}

Skala pengukuran variabel ini mengguakan skala Likert. Untuk menghilangkan jawaban ragu-ragu atau netral, maka setiap pertanyaan hanya diberi jawaban sebanyak empat jawaban. Format jawaban tipe Likert terdiri dari:

1. Untuk jawaban Sangat Tidak Setuju (STS) diberi nilai $=1$

2. Untuk jawaban Tidak Setuju (TS) diberi nilai $=2$ 
3. Untuk jawaban Setuju (S) diberi nilai $=3$

4. Untuk jawaban Sangat Setuju (SS) diberi nilai $=4$

Penentuan penilaian respons masyarakat Sagerat masing-masing variabel di pasar Pinasungkulan Sagerat tentukan berdasarkan skor masing sebagai berikut, Jumlah skor variabel yang berindikator empat;

Jumlah skor $400-700=$ sangat tidak baik

Jumlah skor $700-1000=$ tidak baik

Jumlah skor $1000-1300=$ baik

Jumlah skor $1300-1600=$ sangat baik

Jumlah skor variabel yang berindikator tiga;

Jumlah skor $300-525=$ sangat tidak baik

Jumlah skor $525-750=$ tidak baik

Jumlah skor $750-975=$ baik

Jumlah skor $975-1200=$ sangat baik

Penentuan penilaian respons masyarakat Sagerat terhadap pasar Pinasungkulan Sagerat tentukan berdasarkan total skor dari masingmasing variabel, sebagai berikut;

Jumlah skor $1400-2800=$ Tidak disenangi

Jumlah skor $2801-4200=$ di senangi

Jumlah skor $4201-5600=$ sangat disenangi

\section{Metode Analisis Data}

Berisi tentang bahasan secara deskriptif mengenai jawaban yang diberikan responden pada kuesioner. Data deskriptif ini diterangkan dalam bentuk prosentase dan disajikan dalam bentuk Tabel.

\section{HASIL DAN PEMBAHASAN}

\section{Gambaran Obyek Penelitian}

Pasar tradisional Pinasungkulan Sagerat adalah salah satu pasar di kota Bitung yang didirikan oleh pihak pemerintah dengan bertujuan untuk merelokasikan pasar Girian Bitung, yang telah resmi dijalankan pada bulan februari 2012 . Pembangunann pasar ini telah didirikan oleh pemerintah kota Bitung pada tahun 2010, dengan anggaran sebesar 6,5 miliard rupiah, sampai sekarang pembangunan pasar Pinasungkulan Sagerat masih tetap dilakukan oleh pihak pemerintah guna membuat pasar Pinasungkulan Sagerat menjadi pasar yang lebih baik dari pasarpasar lain yang ada di kota Bitung. Total pengeluaran yang telah dikeluarkan dalam pembangunan pasar Pinasungkulan Sagerat dari tahun 2010 sampai sekarang sebesar Rp. 25.250.000.000,-. Pasar Pinasungkulan Sagerat bertempat di Kelurahan Sagerat Weru dua Kecamatan Matuari Kota Bitung. Pasar ini memiliki lahan keseluruhan dengan luas 6 hektar dan untuk pasar sendiri luas lahan yang di pakai \pm 3 hektar. Invrastruktur yang di miliki olah pasar ini berupa kios sebanyak 208 kios, meja beton pedagang 350 orang, air bersih yang sudah disediakan, listrik, pengaspalan jalan dalam pasar dan sumor bor. Pasar Pinasungkulan Sagerat juga memiliki sarana penunjang fisik SKPD terkait yaitu dinas perikanan dan kelautan, dinas Agribisnis pertanian kota bitung serta dinas perdagangan dan industrian. sedangkan untuk prestasi sendiri pasar sagerat telah terdaftar sebagai perserta lomba pasar sehat nasional pada tahun 2015.

\section{Deskripsi Responden}

Deskripsi responden dalam penelitian dapat dilihat dari jenis kelamin, usia, pendidikan, pekerjaan, pendapatan dan alamat para konsumen yang menjadi responden penelitian mengenai respon masyarakat sagerat terhadap pasar tradisional Pinasungkulan Sagerat.

\section{Karakteristik Responden Berdasarkan Jenis Kelamin}

Sebanyak 100 responden dapat dibedakan menurut jenis kelaminnya dapat dilihat pada Tabel 1.

Tabel 1. Jumlah Responden Berdasarkan Jenis

\begin{tabular}{lccc}
\multicolumn{3}{c}{ Kelamin } & \\
\hline No & Jenis Kelamin & Jumlah (org) & Persentase \\
\hline 1. & Perempuan & 60 & $60 \%$ \\
2. & Laki-laki & 40 & $40 \%$ \\
\hline & Jumlah & 100 & $100 \%$ \\
\hline
\end{tabular}

Tabel 1 menunjukkan bahwa jumlah responden perempuan sebanyak 60 orang dan jumlah responden laki-laki sebanyak 40 orang, maka dapat disimpulkan bahwa sebagian besar (60\%) responden dalam penelitian ini adalah perempuan. Hal ini tentu berdasarkan kenyataan selama ini, jika kaum perempuan lebih banyak 
yang berbelanja di Pasar tradisional dibandingkan kaum laki-laki.

\section{Karakteristik Responden Berdasarkan Usia Responden}

Usia menunjukkan umur responden pada saat penelitian dilakukan. arakteristik usia responden.

\begin{tabular}{cccc}
\multicolumn{4}{c}{ Tabel 2. Jumlah Responden Berdasarkan Usia } \\
\hline No & Usia (thn) & Jumlah (org) & Persentase \\
\hline 1 & $17-25$ & 19 & $19 \%$ \\
2 & $26-35$ & 26 & $26 \%$ \\
3 & $36-49$ & 29 & $29 \%$ \\
4 & $>50$ & 26 & $26 \%$ \\
\hline \multicolumn{5}{c}{ Jumlah } & 100 & $100 \%$ \\
\hline
\end{tabular}

Tabel 2 menunjukkan bahwa jumlah responden berusia dari 17-25 tahun sebanyak 19 persen, kemudian responden dengan usia 26-35 tahun sebanyak 26 persen, responden dengan usia 36-49 tahun sebanyak 29 persen, responden dengan usia lebih dari 50 tahun sebanyak 26 persen, berdasarkan diatas dapat diketahui bahwa responden berumur antara 36 - 49 tahun yaitu 29 persen. Hal ini di sebabkan karena pembangunan kelurahan Sagerat meningkat di 20 tahun terakhir, dalam arti banyak sekali pembangunan perumahanperumahan yang terjadi, kesempatan ini di manfaatkan oleh keluarga-keluaraga yang baru untuk tinggal di seputaran kelurahan Sagerat, untuk itu masyarakat usia 36 - 49 lebih banyak di bandingkan yang lain. Usia 36 - 49 juga memiliki jarak 15 tahun, ini adalah jarak usia terpanjang dari pilihan angket lainnya dan juga usia 36 - 49 adalah usia yang produktif untuk melakukan aktifitas.

\section{Karakteristik Responden Berdasarkan Pekerjaan}

Karakteristik responden berdasarkan pekerjaan atau profesinya.

Pada Tabel 3 menunjukkan bahwa jumlah responden yang mempunyai pekerjaan pelajar/mahasiswa sebanyak 7 responden (7\%), responden Ibu rumah tangga sebanyak 38 responden $(38 \%)$, responden yang bekerja sebagai PNS sebanyak 7 responden (7\%), responden dengan pekerjaan swasta sebanyak
17 responden (7\%), responden yang bekerja sebagai wiraswasta sebanyak 10 responden $(10 \%)$, dan responden dengan pekerjaan lainnya sebanyak 21 responden $(21 \%)$.

Tabel 3. Jumlah Responden Berdasarkan Pekerjaan

\begin{tabular}{clcc}
\hline No & \multicolumn{1}{c}{ Pekerjaan } & Jumlah (org) & Persentase \\
\hline 1 & Pelajar/Mahasiswa & 7 & $7 \%$ \\
2 & Ibu Rumah Tangga & 38 & $38 \%$ \\
3 & PNS & 7 & $7 \%$ \\
4 & Karyawan Swasta & 17 & $17 \%$ \\
5 & Wiraswasta & 10 & $10 \%$ \\
6 & Lain-lain & 21 & $21 \%$ \\
\hline & Jumlah & 100 & $100 \%$ \\
\hline
\end{tabular}

Berdasarkan penggolongan tingkat pekerjaannya, responden yang berprofesi sebagai Ibu rumah tangga memilki responden paling banyak, yaitu sebanyak 38 persen, dalam artian ini sesuai dengan penelitian yang akan di teliti di karenakan ibu rumah tanggalah yang lebih sering berbelanja di pasar dapat dilihat pada Tabel 3.

\section{Karakteristik Responden Berdasarkan Pendidikan}

Karakteristik responden berdasarkan tingkat pendidikan terakhir.

\section{Tabel 4. Jumlah Responden Berdasarkan} Pendidikan

\begin{tabular}{clcc}
\hline No & Pendidikan & Jumlah (org) & Persentase \\
\hline 1 & SD & 8 & $8 \%$ \\
2 & SLTP & 18 & $18 \%$ \\
3 & SLTA & 56 & $56 \%$ \\
4 & Perguruan & 18 & $18 \%$ \\
& Tinggi & & \\
& & & $100 \%$ \\
\hline & Jumlah & 100 &
\end{tabular}

Tabel 4 menunjukkan bahwa jumlah responden paling banyak adalah berpendidikan SLTA sebanyak 56 responden (56\%), diikuti responden berpendidikan SLTP dan Perguruan Tinggi sebanyak 18 responden (18\%), kemudian responden dengan pendidikan SD sebanyak 8 responden (8\%). Responden yang berpendidikan SLTA sebanyak 56 persen. Hal ini menunjukkan Masyarakat Sagerat rata-rata mempunyai pendidikan menengah dan hanya 8 responden yang berhenti melanjutkan sekolah.

\section{Karakteristik Responden Berdasarkan Pendapatan}


Karakteristik responden berdasarkan tingkat pendapatan dapat dilihat pada Tabel 5.

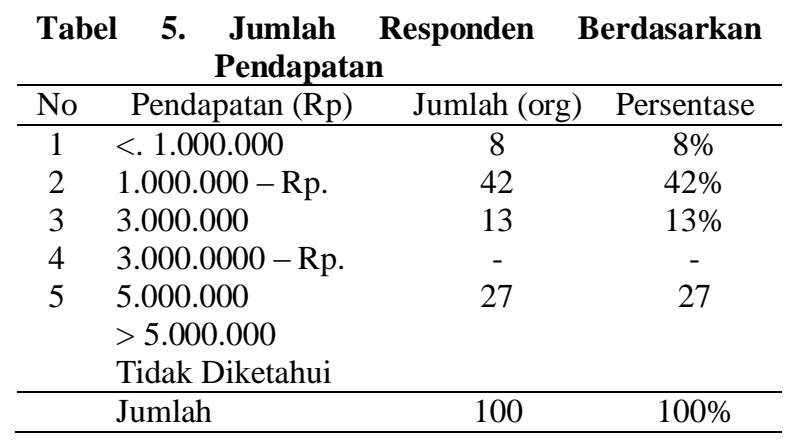

Tabel 5 menunjukkan bahwa tingkat pendapatan masyarakat < Rp. 1.000 .000 berjumlah 8 responden (8\%), pendapatan $\mathrm{Rp}$ 1.000 .000 sampai Rp. 3.000 .000 sebanyak 42 Responden (42\%), sedangkan responden yang pendapatan >Rp. 5.000 .000 berjumlah 0 responden $(0 \%)$, dan 27 responden lainnya tidak di ketahui jumlah pendapatanya. Responden yang berpendapatan Rp.1.000.000 sampai Rp.3.000.000 sebanyak $42 \%$. Hal ini menunjukkan masyarakat Sagerat rata-rata memiliki kehidupan yang menengah.

\section{Karakteristik Responden Berdasarkan Tempat Tinggal}

Karakteristik responden berdasarkan tempat tinggal di bagi menjadi dua bagian yaitu Kelurahan Sagerat Weru Satu dan Kelurahan Sagerat Weru Dua, serta lingkungan dari tempat tinggal responden dapat dilihat pada Tabel 6 .

Tabel 6. Jumlah Responden Berdasarkan Tempat Tinggal

\begin{tabular}{clcc}
\hline No & Tempat Tinggal & Jumlah (org) & Persentase \\
\hline & Sagerat Weru Satu & & \\
1 & Lingkungan I & 12 & $12 \%$ \\
2 & Lingkungan II & 11 & $11 \%$ \\
3 & Lingkungan III & 12 & $12 \%$ \\
4 & Lingkungan IV & 13 & $13 \%$ \\
\hline \multicolumn{2}{l}{ Sagerat Weru Dua } & & \\
5 & Lingkungan I & 10 & $10 \%$ \\
6 & Lingkungan II & 12 & $12 \%$ \\
7 & Lingkungan III & 11 & $11 \%$ \\
8 & Lingkungan IV & 10 & $10 \%$ \\
9 & Lingkungan V & 9 & $9 \%$ \\
\hline & Jumlah & 100 & $100 \%$ \\
\hline
\end{tabular}

Tabel 6 menunjukkan bahwa tempat tinggal dari responden, dimana peneliti mengambil sample responden secara acak, oleh sebab itu jumalah responden dari tiap lingkungan berbeda-beda.

\section{Harga Produk di Pasar Pinasungkulan Sagerat}

Harga adalah salah satu faktor penting dalam proses jual beli yang terjadi di pasar tradisional, di karenakan dengan hargalah kita bisa mengetahui nilai suatu barangan yang akan di beli. Pada Tabel 7 ini menunjukan skor yang di berikan responden terhadap variabel harga dari pasar Pinasungkulan Kota Bitung.

1. 1. Harga Produk . Secara umum harga yang ada di pasar tradisional selalu bisa di beli oleh konsumen, dikarenakan barang-barang yang di jual di pasar Tradisioanl adalah barang untuk kebutuhan sehari-hari, dalam artian adalah barang-barang yang murah. Table 7 juga memperjelas dengan data yang di dapat, dimana bisa di katakan harga yang ada di pasar Pinasungkulan Sagerat cukup terjangku, ini bisa di lihat dengan jumlah masyarakat yang setuju sebanyak 78 persen atau sekitar 78 orang yang setuju, jadi pada umumnya harga barang yang ada di pasar Pinasungkulan Sagerat ini bisa di beli oleh setiap masyarakat, di perkuat juga dengan tidak ada responden yang sangat tidak setuju dengan hal ini.

2. Kesesuaian kualitas dengan Harga yang di tawarkan. Harga yang sesuai kualitas barang yang ditawarkan tentunya berperan penting dalam penilaian masyarakt terhadap pasar tersebut. Hal ini juga yang terjadi di Pasar Pinasungkulan Sagerat, dimana penilaian ini cukup merata sekitar 39 responden yang memberi skor 2 atau tidak setuju dengan hal ini, dan 52 responden yang mengatakan setuju dengan harga yang di tawarkan sesuai dengan kualitas, bahkan 9 responden sangat setuju.

3. Variasai harga produk yang ada di Pasar Pinasungkulan Sagerat. Umumnya harga di dalam pasar selalu bervariasi, dikarenakan banyaknya penjual dan banyaknya baranga di pasar, demikian juga yang terjadi di Pasar Pinasungkulan Sagerat di mana harga selalu bervariasi, antara pedagang dan pedagang yang lain memiliki harga yang berbeda-beda. Terbukti dengan 59 responden setuju akan hal ini dan 7 responden sangat setuju dengan harga produk yang ada di pasar ini sangat bervariasi, tetapi juga ada sekitar 34 responden yang mengatakan bahwa harga produk di pasar ini tidak bervariasi, dalam hal ini responden mengatakan bawah harga sebagian besar yang ada di pasar 
kebanyakan sama, walaupun ada yang tidak sama tetapi bisa di tawar dan menjadi harga yang sama dengan pedagang yang lain. Pada 3 indikator di atas, kita bisa melihat bahwa harga yang di tawarkan sesuai kualitas memiliki skor terkecil atau sekitar 270, ini dikarenakan jumlah barang yang di jual terbatas mengakibatkan harga barang seringkali di atas normal barang tersebut, akan tetapi harga yang di tawarkan tetap terjangkau, seperti dari hasil di atas, indikator tentang harga yang terjangkau mendapat poin tertinggi berjumlah 308 , dengan total skor yang ada untuk variabel harga berjumlah 851, yang artinya variabel harga masih dalam kategori baik oleh masyarakat dan harga yang ada di Pasar Pinasungkulan Sagerat masih terjangaku oleh masyarakat.

\section{Pelayanan di Pasar Pinasungkulan Sagerat}

Pelayanan merupakan faktor penting dalam meningkatkan penjualan, karena dengan pelayanan yang baik membuat konsumen bisa tertarik untuk kembali lagi untuk berbelanja. Tabel 8 menunjukan skor yang di dapat dari responden tentang variabel pelayanan yang ada di pasar Pinasungkulan Kota Bitung.

1. Pelayanan yang di berikan kepada konsumen cepat. Pelayanan yang cepat pastinya akan memuaskan konsumen, karena dengan pelayanan yang cepat tidak membuat konsumen menunggu, dalam hal ini konsumen masih bisa menyelesaikan pekerjaan yang lain tanpa harus menunggu proses jual beli yang lama. Tabel 8 menunjukan pelayanan yang di berikan pembeli terhadap penjual di pasar pinasungkulan dianggap baik bagi masyarakat dikarenakan sebagian responden setuju dengan pelayanan yang cepat dari penjual di pasar tersebut, terbukti sekitar 73 responden yang setuju akan hal ini, sedangkan hanya 11 responden yang tidak setuju kalau Pasar Pinasungkulan Sagerat memiliki pelayanan yang cepat.

2. Keramahan penjual terhadap konsumen. Dari hasil wawancara kuesioner seringkali responden mengatakan bahwa Pasar Pinasungkulan Sagerat memiliki pelayanan yang ramah dari pembeli. Terbukti ada sekitar 62 responden yang setuju dengan hal ini, dan hanya 7 responden yang tidak setuju akan hal ini. Data ini di pertegas dengan hasli wawancara dengan Kabag Pengawasan dinas pasar mengatakan bahwa "sebagian besar penjual yang ada di pasar Pinasungkulan Sagerat adalah masyarakat setempat". Dalam artian bahwa komunikasi yang terjadi antara penjual dan pembeli tidak nanti adanya pasar tersebut tetapi juga sebagai tetangga tempat tinggal, tentunya ini mempererat hubungan baik antara sesama.

3. Kepentingan kepuasan pembeli bagi para penjual . Penilaian masyarakat terhadap penjual yang menerapakan bahwa kepuasan konsumen selalu di utamakan cukup berimbang, dilihat dari hasil di atas 41 responden tidak setuju dengan hal ini di karenakan responden menganggap bahwa penjual lebih mementingkan keuntungan dari pada kepuasan konsumen. Ini bisa di lihat dengan sulitnya menurunkan harga yang telah di tentukan penjual, tetapi ada sekitar 50 responden yang setuju dengan ini dan ada 9 responden yang sangat setuju kalau kepuasan konsumen menjadi yang terutama di karenakan reponden mengatakan bahwa barang-barang yang di beli layak pakai dan di konsumsi. Data pada tabel 8 kita bisa melihat bahwa pelayanan yang cepat memiliki skor tertinggi yaitu 305, artinya pasar Pinasungkulan Sagerat memiliki pelayanan yang cepat, dimana pembeli langsung di layani oleh penjual. Skor terkecil dengan jumlah 268 yaitu kepuasan konsumen menjadi hal yang utama bagi penjual, meski pelayanan yang ada di pasar Pinasungkulan Sagerat masih ada kekurangan tetepi sebagian masyarakat sekitar merasa bahwa pelayanan yang ada sudah baik, terbukti jumlah skor yang di dapat dari indikator variabel pelayanan berjumlah 857 yang artinya pasar Pinasungkulan Sagerat memiliki pelayanan dalam kategori baik.

\section{Lokasi Pasar Pinasungkulan Sagerat}

Lokasi sangat berpengaruh dalam membangun suatu usaha, dimana apabila lokasi yang di pilih strategis dapat membuat banyak konsumen yang datang berbelanja. Tabel 9 ini skor dari responden yang menunjukan apakah lokasi pasar Pinasungkulan Sagerat berada dilokasi yang strategis.

1. Transportasi yang ada untuk pergi ke Pasar Pinasungkulan Sagerat. Dari hasil yang di dapat tentang kemudahan mendapatkan sarana transportasi untuk ke pasar Pinsungkulan Sagerat sangat bervariasai tentang setuju atau tidak setuju akan hal ini, bisa di lihat ada sekitar 
8 responden yang sangat tidak setuju. Kenyataanya memang sampai sekarang tidak ada jalur transportasi khususnya untuk kendaraan umum. Inilah yang membuat begitu banyak responden yang tidak setuju dengan jalur akses transoptasi yang mudah, tetapi juga ada ada yang berpendapat lain, bisa di lihat dari tabel 9 sekitar 47 responden yang mengatakan pasar Pinasungkulan Sagerat memiliki akses transportasi dengan mengatakan bahwa walaupun tidak adanya kendaraan umum tetapi jasa ojek cukup banyak dan dekat baik dari tempat tinggal pembeli ataupun di sekitran pasar.

2. Waktu tempuh untuk ke Pasar Pinasungkulan Sagerat. Pasar Pinasungkulan Sageat bertempat di Kelurahan sagerat weru 2, Kecamatan Mautari Kota bitung, ini sangat berdekatan dengan sebagian besar masyarakat Sagerat, dalam hal lamanya untuk ke pasar Pinasungkulan Sagerat sebagain masyarakat merasa setuju akan hal ini di karenakan pasar itu lebih cepat di tempuh dari pada ke pasar lainnya. Terbukti 43 responden merasa setuju dan 52 responden sangat setuju bahwa tidak memerlukan waktu yang lama untuk ke pasar tersebut.tetapi ada sekitar 5 responden yang tidak setuju akan hal ini.

3. Pasar Pinasungkulan Sagerat berada di tempat yang cukup strategis. Satu diantara faktor yang menentukan ramainya pasar tersebut adalah tempat di mana pasar itu berada. Tempat yang strategis akan membuat pasar itu memiliki banyak penjual dan pembeli. Dalam hal ini ada sekitar 14 responden yang sangat tidak setuju dan 36 responden mengatakan tidak setuju bahwa lokasi Pasar Pinasungkulan Sagerat berada di tempat yang strategis di karenakan pasar yang bertempat jauh dari jalan raya Bitung, mesih belum terlalu besar pembangunan pemukiman, dan belum adanya jalur transportasi untuk kendaraan umum. Namun sebaliknya 46 responden merasa setuju dengan hal ini dan 4 responden sangat setuju. Responden mengatakan bahwa pasar Pinasungkulan Sagerat bertempat di lokasi yang strategis, bisa berjalan kali, tidak memerlukan waktu yang, dan nantinya apa bila pertumbuhan pembangunan kedepan akan membuat pasar ini sangat di butuhkan karena pembangunan pemukiman warga sedang meengarah ke daerah pasar tersebut.
4. Lokasi pasar yang berada di pusat keramaian. Indikator ini respons masyarakat cukup berimbang di mana 7 responden yang sangat tidak setuju, 37 responden yang tidak setuju, 41 responden mengatakan setuju, dan 15 responden mengatakan sangat setuju bahwa pasar Pinasungkulan Sagerat berada di pusat keramain, hal ini di sebabakan ada yang merasa bahwa pasar Pinasungkulan Sageat tidak berada di pusat keramaian karena berada jauh dari kelurahan-kelurahan yang lain, sedangkan ada yang mengatakan pasar Sagerat berada di pusat keramaian walaupun terkhusukan untuk warga sekitar. Empat indikator di atas, kita bisa melihat bahwa untuk ke pasar Pinasungkulan Sagerat tidak memerlukan waktu banyak, terbukti dengan skor yang tertinggi dari lainnya dengan jumlah 347. Ini terjadi karena pasar Pinasungkulan Sagerat berada di seputaran masyarakat sagerat. Namun pasar ini masih dianggap tidak strategis oleh masyarakat sekitar, bisa di lihat dengan jumlah skor yang terendah dari semua indikator dikarenakan lokasi pasar yang jauh dari jalan utama dan juga berada di daerah yang masih kurang berkembang untuk pemukiman warga. Meski skor dari variabel lokasi pasar sagerat berjumlah 1108, yang artinya pasar sagerat meiliki lokasi yang strategis bagi masyarakat sekitar, namun memang masih banyak hal-hal yang harus diperhatikan demi menunjang pasar yang lebih baik, terutama jalur transportasi yang belumn disediakan oleh pemerintah.

\section{Keragaman Barang di Pasar Pinasungkulan Sagerat}

Banyaknya barang yang di jual bisa meningkatkan jumlah konsumen yang datang berbelanja, hal ini juga harus diterapkan didalam pasar Tradisional agar supaya konsumen yang datang berbelanja bisa meningkat. Tabel 10 menunjukan tentang bagaimana barang-barang yang di jual di pasar pinasungkulan Sagerat.

1. 1. Kelengkapan barang yang ditawarkan di Pasar Pinasungkulan Sagerat. Pasar Pinasungkulan Sagerat memang masih banyak yang harus di perhatikan terutama soal kelengkapan barang yang di jual, penjualan daging mentah yang tidak ada di pasar tersebut, untuk itu ada sekitar 9 orang yang sangat tidak setuju dan 49 orang yang tidak setuju kalau 
produk yang ada di pasar pinasungkulan lengkap, tetapi juga ada 37 responden dan 5 responden yang setuju bahkan sangat setuju bahwa Pasar Pinasungkulan Sagerat lengkap, dalam hal ini produk untuk kebutuhan hari-hari

2. Produk yang ditawarkan di Pasar Pinasungkulan Sagerat cukup bervariasi. Data pada Tabel 10 kita bisa melihat bahwa masyarakat memiliki penilaian yang merata soal produk yang bervariasi di pasar tersebut, sekitar 46 responden yang tergolong tidak setuju dan 54 responden yang di golongkan setuju terhadap indikator ini, seperti yang kita ketahui bersama memang pasar memiliki produk yang beraneka ragam, meski demikian pasar Pinasungkulan Sagerat masih memerlukan bertambahnya barang-barang yang belum ada di pasar tersebut.Persediaan barang yang ada di Pasar Pinasungkulan Sagerat. Pasar harus memiliki persediaan yang baik agar supaya barang yang akan di jual tidak akan kehabisan. Masyarakat mennilai terhadap Pasar Pinasungkulan Sagerat yaitu 2 responden yang sangat tidak setuju dan 56 respoden tidak setuju, artinya responden merasa bahwa pasar ini tidak memiliki persediaan yang baik karena sering kali apa bila sudah menjelang sore hari barang yang di jual mulai sedikit, ini juga di sebabkan karena para penjual yang mulai berpindah ke pasar lain menjelang sore hari, namun ada juga yang merasa bahwa pasar pinasungkulan memiliki persediaan yang baik. Bisa di lihat dengan ada 36 responden yang setuju dan 6 responden yang sangat setuju bahwa persediaan barang di pasar pinasungkulan sangat baik, dengan asumsi bahwa mereka selalu mendapatkan apa yang mereka perlukan.

3. Keragaman merek barang yang ada di pasar Pinasungkulan. Data pada Tabel 10 menunjukan 63 responden tidak setuju bahwa di pasar Pinasungkulan Sagerat memiliki produk dengan merek yang berbeda-beda dikarenakan sebagain responden merasa bahwa sebagai besar merek yang ada di pasar tersebut sama, dan juga cukup banyak produk yang tidak bermerek, tetapi juga ada 39 responden yang mengatakan bahwa variasi merek terdapat di pasar Pinasungkulan Sagerat, bahkan 8 responden sangat setuju kalo merek di pasar Pinasungkulan Sagerat berbeda-beda. Variabel keragaman barang memiliki skor yang berjumlah 999, yang artinya bahwa untuk keragaman barang yang ada di pasar Pinasungkulan Sagerat di nilai oleh masyarakat adalah kurang beragam dan masih ada kekurangan-kekurangan yang harus di perhatikan. Dari 4 variabel yang telah di teliti jumlah skor keseluruhan Pasar Pinasungkulan Sagerat adalah 3815, yang artinya pasar ini di senangi oleh masyarakat sekitar, melalui 4 indikator yang di teliti yang diteliti yaitu harga, pelayanan, lokasi dan keragaman barang. Namun ada sebagaian masyarakat yang mengatakan bahwa Pasar Pinasungkulan Sagerat memiliki kekurangankekurangan dan memberikan skor yang rendah atau tidak setuju, dalam hal ini;

4. Belum tersedianya jalur transportasi angkutan umum, Ini membuat masyarakat sekitar lebih memilih pasar lain dalam hal ini pasar Girian Bitung, di karenakan apa bila ingin membeli dalam jumlah yang banyak, masyarakat harus mengeluarkan biaya tambahan dalam menggunakan ojek.

5. Persediaan barang yang tidak memadai, penjual yang hanya menyediakan jumlah barnag yang sedikit membuat masyarakat sekitar kesulitan memperoleh barang yang dibutuhkan apabila ingin berbelanja di sore hari

1. Penjual yang berpindah berjualan di pasar lain setelah menjelang siang hari. Keberadaan pasar sagerat untuk sekarang ini lebih terfokus untuk masyarakat sekitar di karenakan tidak adanya jalur transportasi umum yang akan membuat pasar ini di datangi oleh masyarakat yang jauh dari pasar tersebut. hal ini membuat penjual berpindah tempat setelah menejelang siang, karena jumlah pembeli yang ada di pasar tersebut semakin berkurang.

2. Belum tersedianya daging mentah dalam hal ini daging sapi, apabila masyarakat sagerat ingin mengadakan pesta yang memerlukan variasi daging mentah yang banyak, mereka lebih memilih berbelanja di pasar lain. Bukan hanya untuk membeli daging mentah namun sekaligus membeli keperluan-keperluan yang di butuhkan. 
Table 7. Variabel Harga di pasar Pinasungkulan Sagerat

\begin{tabular}{|c|c|c|c|c|}
\hline Pertanyaan & Skor & Jumlah Orang & Presentase & Bobot \\
\hline \multirow{4}{*}{ Harga Produk Di pasar Pinasungkulan Terjangkau } & 1 & - & $0 \%$ & 0 \\
\hline & 2 & 7 & $7 \%$ & 14 \\
\hline & 3 & 78 & $78 \%$ & 234 \\
\hline & 4 & 15 & $15 \%$ & 60 \\
\hline Jumlah & & 100 & $100 \%$ & 308 \\
\hline \multirow{4}{*}{ Harga yang di tawarkan sesuai dengan kualitas } & 1 & - & $0 \%$ & 0 \\
\hline & 2 & 39 & $39 \%$ & 78 \\
\hline & 3 & 52 & $52 \%$ & 156 \\
\hline & 4 & 9 & $9 \%$ & 36 \\
\hline Jumlah & & 100 & 100 & 270 \\
\hline \multirow{4}{*}{ Harga Produk yang bervariasi } & 1 & - & $0 \%$ & 0 \\
\hline & 2 & 34 & $34 \%$ & 68 \\
\hline & 3 & 59 & $59 \%$ & 177 \\
\hline & 4 & 7 & $7 \%$ & 28 \\
\hline \multirow[t]{2}{*}{ Jumlah } & & 100 & $100 \%$ & 273 \\
\hline & Total & & & 851 \\
\hline
\end{tabular}

Tabel 8. Variabel Pelayanan di pasar Pinasungkulan Kota Bitung

\begin{tabular}{|c|c|c|c|c|}
\hline Pertanyaan & Skor & Jumlah Orang & Presentase & Bobot \\
\hline \multirow{4}{*}{ Pelayanan yang diberikan kepada konsumen cepat } & 1 & - & $0 \%$ & 0 \\
\hline & 2 & 11 & $11 \%$ & 22 \\
\hline & 3 & 73 & $73 \%$ & 219 \\
\hline & 4 & 16 & $16 \%$ & 64 \\
\hline Jumlah & & 100 & $100 \%$ & 305 \\
\hline \multirow{4}{*}{ Pelayanan penjual yang ramah terhadap konsumen } & 1 & - & $0 \%$ & 0 \\
\hline & 2 & 7 & $7 \%$ & 14 \\
\hline & 3 & 62 & $62 \%$ & 186 \\
\hline & 4 & 21 & $21 \%$ & 84 \\
\hline Jumlah & & 100 & $100 \%$ & 284 \\
\hline \multirow{4}{*}{$\begin{array}{l}\text { Kepuasan konsumen menjadi yang terutama bagi } \\
\text { para penjual }\end{array}$} & 1 & - & $0 \%$ & 0 \\
\hline & 2 & 41 & $41 \%$ & 82 \\
\hline & 3 & 50 & $50 \%$ & 150 \\
\hline & 4 & 9 & $9 \%$ & 36 \\
\hline Jumlah & & 100 & $100 \%$ & 268 \\
\hline Total & & & & 857 \\
\hline
\end{tabular}

Table 9. Variabel Lokasi pasar Pinasungkulan Kota Bitung

\begin{tabular}{|c|c|c|c|c|}
\hline Pertanyaan & Skor & Jumlah Orang & Presentase & Bobot \\
\hline Memiliki akses transportasi yang mudah & 1 & 8 & $8 \%$ & 8 \\
\hline \multirow[t]{3}{*}{ untuk ke Pasar Pinasungkulan Sagerat } & 2 & 36 & $36 \%$ & 72 \\
\hline & 3 & 47 & $47 \%$ & 141 \\
\hline & 4 & 9 & $9 \%$ & 36 \\
\hline Jumlah & & 100 & $100 \%$ & 257 \\
\hline Tidak memerlukan waktu yang lama & 1 & - & $0 \%$ & 0 \\
\hline \multirow[t]{3}{*}{ untuk ke Pasar Pinasungkulan Sagerat } & 2 & 5 & $5 \%$ & 10 \\
\hline & 3 & 43 & $43 \%$ & 129 \\
\hline & 4 & 52 & $52 \%$ & 208 \\
\hline Jumlah & & 100 & $100 \%$ & 347 \\
\hline \multirow{4}{*}{$\begin{array}{l}\text { Pasar Pinasungkulan Sagerat berada di } \\
\text { tempat yang strategis }\end{array}$} & 1 & 14 & $14 \%$ & 14 \\
\hline & 2 & 36 & $36 \%$ & 72 \\
\hline & 3 & 46 & $46 \%$ & 138 \\
\hline & 4 & 4 & $4 \%$ & 16 \\
\hline Jumlah & & 100 & $100 \%$ & 240 \\
\hline Lokasi pasar pinasungkulan berada & 1 & 7 & $7 \%$ & 7 \\
\hline \multirow[t]{3}{*}{ ditempat pusat keramainan } & 2 & 37 & $37 \%$ & 74 \\
\hline & 3 & 41 & $41 \%$ & 123 \\
\hline & 4 & 15 & $15 \%$ & 60 \\
\hline Jumlah & & 100 & $100 \%$ & 264 \\
\hline
\end{tabular}


Table 10. Variabel Keragaman Barang di Pasar Pinasungkulan Sagerat

\begin{tabular}{|c|c|c|c|c|}
\hline Pertanyaan & Skor & Jumlah Orang & Presentase & Bobot \\
\hline \multirow[t]{4}{*}{ Pasar pinasungkulan memiliki produk yang lengkap } & 1 & 9 & $9 \%$ & 9 \\
\hline & 2 & 49 & $49 \%$ & 98 \\
\hline & 3 & 37 & $37 \%$ & 111 \\
\hline & 4 & 5 & $5 \%$ & 20 \\
\hline Jumlah & & 100 & $100 \%$ & 238 \\
\hline Produk yang ditawarkan di Pasar Pinasungkulan & 1 & 1 & $1 \%$ & 1 \\
\hline \multirow[t]{3}{*}{ Sagerat bervariasi } & 2 & 45 & $45 \%$ & 90 \\
\hline & 3 & 44 & $44 \%$ & 141 \\
\hline & 4 & 7 & $7 \%$ & 8 \\
\hline Jumlah & & 100 & $100 \%$ & 240 \\
\hline \multirow{5}{*}{$\begin{array}{l}\text { Pasar Pinasungkulan Sagerat memiliki persediaan } \\
\text { barang yang baik }\end{array}$} & 1 & 2 & $2 \%$ & 2 \\
\hline & 2 & 56 & $56 \%$ & 112 \\
\hline & 3 & 36 & $36 \%$ & 108 \\
\hline & 4 & 6 & $6 \%$ & 24 \\
\hline & & 100 & $100 \%$ & 246 \\
\hline \multirow{5}{*}{$\begin{array}{l}\text { Produk-produk di pasar Pinasungkulan memiliki } \\
\text { merek-merek yang berbeda }\end{array}$} & 1 & - & & 0 \\
\hline & 2 & 53 & $53 \%$ & 106 \\
\hline & 3 & 39 & $39 \%$ & 117 \\
\hline & 4 & 8 & $8 \%$ & 32 \\
\hline & & 100 & $100 \%$ & 255 \\
\hline Total & & & & 999 \\
\hline
\end{tabular}

\section{KESIMPULAN DAN SARAN}

\section{Kesimpulan}

Berdasarkan penelitian dan hasil analisis data respon masyarakat sagerat terhadap Pasar Pinasungkulan Sagerat dapat disimpulkan sebagai berikut: Pasar Pinasungkulan Sagerat memiliki harga yang terjangkau dan juga kualitas yang ada cukup sesuai dengan harga yang ditawarkan. Pasar Pinasungkulan Sagerat juga memiliki hargaharga produk yang cukup bervariasi. Pelayanan yang ada di pasar Pinasungkulan Sagerat dinilai baik oleh masyarakat di karenakan, pelayanan penjual yang cepat terhadap pembeli, selain itu penjual yang ada di pasar ini begitu ramah terhadap pembeli dan kepuasan konsumen cukup menjadi yang terutama bagi para beberapa penjual. Pasar Pinasungkulan Sagerat berada ditempat yang strategis dan berada ditempat yang dekat dengan keramaian pemukiaman, dengan jarak tempuh yang tidak memerlukan waktu lama dan juga pasar ini memiliki jalur transportasi yang cukup mudah, disamping itu pasar ini juga lebih nyaman untuk

berbelanja karena jauh dari jalan umum dan memiliki lahan yang cukup besar dan teratur.
Keragaman barang yang ada di pasar Pinasuangkulan Sagerat dinilai tidak beragam, dikarenakan persediaan barang yang kurang bagus dan jumlah barang yang masih kurang. Empat variabel di atas dapat dilihat bahwa secara keseluruhan bahwa Pasar Pinasungkulan Sagerat disenangi oleh masyarakat. Walaupun masih banyak hal-hal yang harus di benahi untuk kemajuan pasar ini, mulai dari belum adanya jalur transportasi untuk ke pasar tersebut, tidak adanya yang berjualan daging mentah dalam hal ini dagging sapi, dan juga para penjual yang berpindah tempat menjelang siang hari, membuat persediaan barang di pasar tersebut mulai habis, namun bagi masyarakat Sagerat pasar Pinasungkulan ini sangat membantu untuk keperluan kehidupan seharihari.

\section{Saran}

Berdasarkan hasil penelitian ini dapat diberikan saran-saran sebagai berikut: Variabel harga, pelayanan, lokasi dan keragaman barang berpengaruh signifikan terhadap respon masyarakat terhadap pasar Pinasungkulan, oleh karena itu pihak manajemen pasar tersebut sebaiknya memperhatikan faktor-faktor tersebut agar dapat meningkatkan respon yang baik dari masyarakat sekitar. Pihak manajemen pasar bisa lebih memperhatikan kekurangan-kekurangan 
di pasar Pinasungkulan Sagerat seperti; tidak adanya jalur transportasi ke lokasi pasar, para penjual yang berpindah tempat, tidak tersedianya daging mentah di pasar Pinasungkulan Sagerat, Untuk itu sebaiknya, pedagang Pasar pinasungkulan menjual produk yang belum ada di pasar tersebut, agar supaya lebih banyk lagi pembeli yang datang dan masyarakat sekitar tidak perlu berbelanja di pasar lain. Pemerintah dalam hal ini yang berperan penting atas terjadinya Pasar Pinasungkulan Sagerat tentunya harus terus memperhatikan kekurangan-kekurangan dari pasar tersebut mulai dari pedagang yang berkurang dan juga jalur transportasi yang belum ada. Kiranya pemerintah mempunyai kebijakan-kebijakan yang baru dalam meningkatkan kemajuan pasar Pinasungkulan agar supaya lebih banyak lagi masyarakat berbelanja di pasar tersebut.

\section{DAFTAR PUSTAKA}

Damsar, 1997, Sosiologi Ekonomi, Jakarta, PT Raja Grafindo Persada.

Djarwanto dan Pangestu Subagyo. 2000. Statiktik Induktif. Edisi Keempat.Cetakan Kelima. BPFE. Yogyakarta.

Ehrenberg, R. Dan R. S. Smith. 2003. Modern Labor Economics. Pearson Education Inc. New York.

Koentjarabungrat, 1990. Aspek Manusia Dalam Penelitian Masyarakat. PT Gramedia. Jakarta.

Primack, B.R., dkk. 1998. A Promer Of Conservation Biology (Biologi Konservasi).Yayasan Obor indonesia. Jakarta.

Purwadinata, 1999.Psikologi Komunikasi, Jakarta: Universitas Terbuka.
Rakhmat, Jalaludin, 2005. Psikologi Komunikasi. Remaja Rosdakarya, Bandung.

Setiadi, Elly. M. 2006. Ilmu Sosial Dan Budaya Dasar.Kencana. Jakarta.

Suardiman, Siti Partini, Psikologi Sosial, Yogyakarta: Studing, 1993

Sugiyono. 2005. Metode Penelitian Bisnis. Cetakan Kedelapan. CV Alfabeta.Bandung.

Surwono, Sarlito Wirawan, 1995. Teori-teori Psikologi Sosial, Rasa Grafindo perseda. Jakarta.

Tandjung, Jenu Widjaja. 2004. Marketing Management : Pendekatan Pada NilaiNilai Pelanggan. Edisi Kedua. Cetakan Kedua. Bayumedia Publishing.Malang.

Tjiptono, Fandy dan Gregorius Chandra. 2005. Service Quality \& Satisfaction.Edisi Satu. Andi.Yogyakarta 